Goldschmidt 2021 Abstract

https://doi.org/10.7185/gold2021.3492

\section{Characterization of borosilicates bearing rocks of Larsemann Hills, East Antarctica: Implications for their polygenetic evolution}

\author{
MOHAMMAD SADIQ ${ }^{1}$, DEVSAMRIDHI ARORA ${ }^{2}$, AMIT \\ DHARWADKAR ${ }^{1}$, SANDIP K. ROY ${ }^{1}$, NARESH C. PANT ${ }^{3}$, \\ JOY G. GHOSH ${ }^{1}$ AND RAGHURAM - ${ }^{1}$ \\ ${ }^{1}$ Geological Survey of India \\ ${ }^{2}$ Indian Institute of Technology, Bombay \\ ${ }^{3}$ University of Delhi \\ Presenting Author: devsamridhiarora@gmail.com
}

Borosilicates bearing high-grade metamorphic rocks have been reported only from a few localities within the various Gondwanaland fragments. One such locality is in Larsemann Hills, East Antarctica, especially in the Stornes and Brattenevet Peninsulas. Presence of two ororgenies separated by $\sim 300 \mathrm{Ma}$ with the younger being of Pan-African age, have been proposed in this sector. Borosilicate minerals (dominantly tourmaline, prismantine and grandidierite) are concentrated in three major lithologies: pegmatite, tourmaline quartzite and pelitic granulites.

Borosilicates bearing metasedimentaries dominantly consist of coarse grains of prismantine, grandidierite and tourmaline, generally segregated in thin separate layers. The matrix minerals include sillimanite, cordierite, quartz, plagioclase and K-feldspar. XRD data indicates dravite, schorl, nimite, hydroxylapatite in quartzite. Pegmatite comprises of quartz, K-feldspar, plagioclase, prismantine, tourmaline with minor amount of biotite, apatite and cordierite. Typical graphic intergrowth of prismantine and quartz is present. In metasedimentaries, overgrowth of tourmaline around grandidierite and prismantine; presence of tourmaline and grandidierite inclusions in prismantine and; growth of grandidierite-quartz and grandidierite-cordierite symplectites (Fig 1) indicate polygenetic development of B-phases.

B content reaches $\sim 7798 \mathrm{ppm}$ in massive tourmaline quartzite that contains abundant, aligned aggregates of grandidierite prisms and tourmaline. B-rich lithounits are enriched in $\mathrm{P}_{2} \mathrm{O}_{5}(\sim 3$ $w t \%)$. Most of the metasedimentaries are enriched in $\mathrm{Cr}, \mathrm{V}$ and Y. REE patterns of metasedimentaries show LREE enrichment, prominent negative Eu-anomaly and slight Ce-anomaly, indicating hydrothermal system in marine environment. Tourmaline, prismantine and grandidierite from the borosilicate bearing pegmatite and metasedimentaries were analysed for trace elements and REE by LA-Q-ICPMS. Distinct REE patterns of matrix and inclusion borosilicates confirm their polygenetic evolution (Fig 2: LREE depletion in some of the grandidierite grains present as inclusions in prismantine grains). Chemical dating of texturally constrained monazites from paragneiss suggest Pan-African ( $450 \mathrm{Ma})$ origin of the B-rich rocks. These rocks provide excellent markers to understand the petrogenetic diversity of the rare borosilicate minerals as well as their precursors and hydrothermal-metamorphic evolution of Boron rich rocks. Present work is an integrated approach for the identification of B-rich phases and characterization of implications for their role in the Pan-African orogenesis.

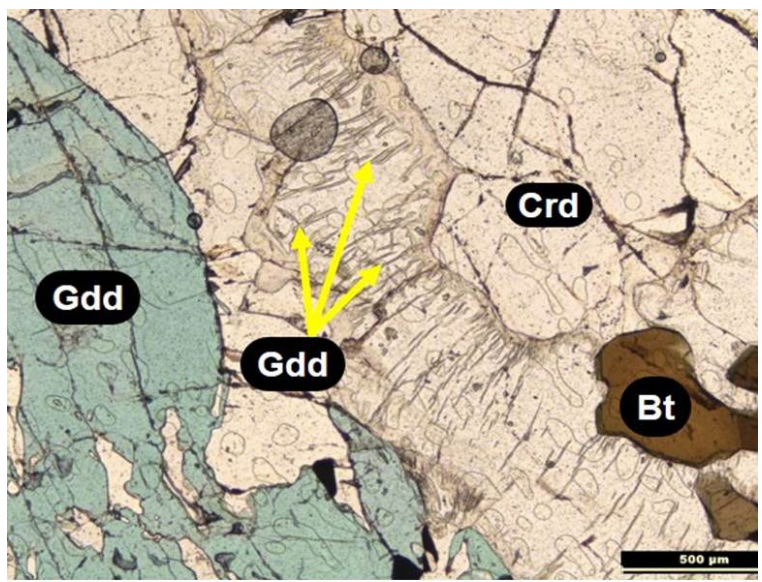

Figure 1: Grandidierite prisms and grandidierite-cordierite symplectitic growth present in borosilicate rich metapelite from Stornes Peninsula, Larsemann Hills in East Antarctica.

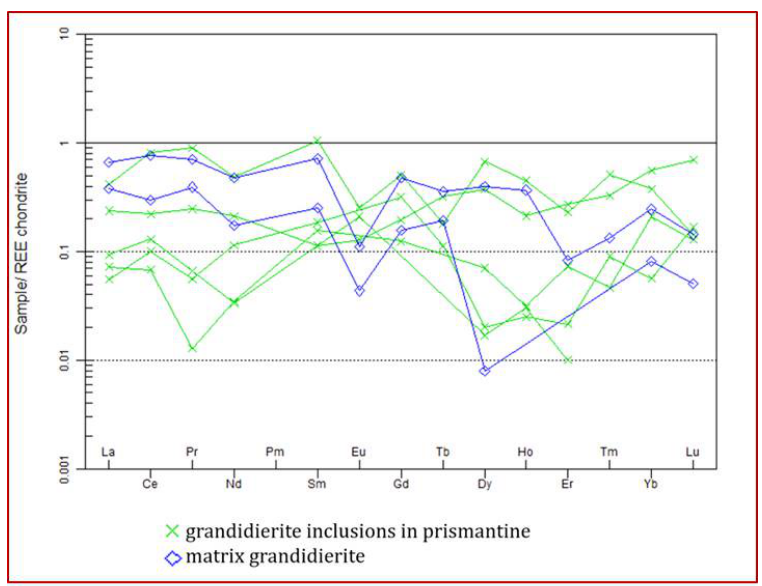

Figure 2: Chondrite-normalized REE plot of matrix and inclusion grandidierite. Note: the chondrite values are from Nakamura (1974). 